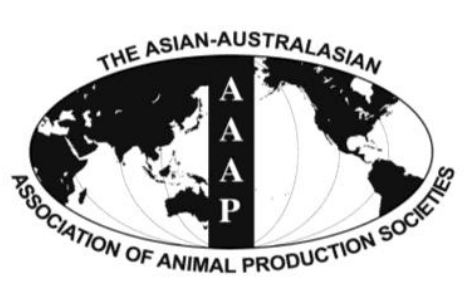

Open Access

Asian Australas. J. Anim. Sci.

Vol. 28, No. 11 : 1641-1648 November 2015

http://dx.doi.org/10.5713/ajas.15.0181

www.ajas.info

pISSN 1011-2367 elSSN 1976-5517

\title{
Dietary Protein Sources Affect Internal Quality of Raw and Cooked Shell Eggs under Refrigerated Conditions
}

\author{
X. C. Wang ${ }^{1,2, a}$, H. J. Zhang ${ }^{2, \text {,a }}$, S. G. Wu ${ }^{2}$, H. Y. Yue ${ }^{2}$, J. Wang $^{2}$, J. Li ${ }^{1, *}$, and G. H. Qi ${ }^{2}$,* \\ ${ }^{1}$ College of Animal Nutrition and Feed Science, Northeast Agricultural University, Harbin 150030, China \\ ${ }^{2}$ Key Laboratory of Feed Biotechnology of Ministry of Agriculture, Feed Research Institute, \\ Chinese Academy of Agricultural Sciences, Beijing 100081, China
}

\begin{abstract}
This study was conducted to evaluate the effects of various protein sources (soybean meal, SBM; cottonseed protein, CSP; double-zero rapeseed meal, DRM) on the internal quality of refrigerated eggs. A total of 360 laying hens (32 wk of age) were randomly allotted to six treatment groups (five replicates per treatment) and fed diets containing SBM, CSP, or DRM individually or in combination with equal crude protein content (SBM-CSP, SBM-DRM, and CSP-DRM) as the protein ingredient(s). A $6 \times 3$ factorial arrangement was employed with dietary types and storage time $(0 \mathrm{~d}, 2 \mathrm{wk}$, and $4 \mathrm{wk})$ as the main effects. After $12 \mathrm{wk}$ of diet feeding, a total of 270 eggs were collected for egg quality determination. The egg Haugh unit (HU) in the CSP, SBM-DRM, and DRM groups were significantly lower than those in the SBM and SBM-CSP groups. The hardness and springiness of the cooked yolk in the CSP group were significantly higher than those in the other treatment groups. A lower HU, lower yolk index and higher albumen $\mathrm{pH}$ were observed in the DRM group compared to the SBM and SBM-CSP groups when the eggs were stored to 4 wk, and the HU was improved in the CSP-DRM group compared to the DRM group $(\mathrm{p}<0.05)$. Higher yolk hardness was observed in the CSP group compared to the other groups during storage $(\mathrm{p}<0.05)$, but the hardness of the cooked yolk in the SBM-CSP and CSP-DRM groups showed no difference in comparison to the SBM group. In conclusion, CSP may ameliorate the negative effects of DRM on the HU of refrigerated eggs, and SBM or DRM may alleviate the adverse effects of CSP on yolk hardness. (Key Words: Plant Protein Ingredient, Internal Quality, Refrigeration, Chicken Egg)
\end{abstract}

\section{INTRODUCTION}

The hugely fluctuating prices of feed protein resources, especially high-quality protein ingredients such as soybean meal (SBM), have been a limiting factor in poultry production and are becoming increasingly challenging. One solution to the current situation is to develop alternative, locally available protein feedstuffs. Numerous investigations have focused on the effects of dietary protein levels on the quality of fresh eggs (Tarasewicz et al., 2006; Rao et al., 2011; Li et al., 2013). However, studies on the

\footnotetext{
* Corresponding Authors: Jie Li. Tel: +86-451-55191395, Fax: +86-451-55191395, E-mail: lijie3456@sina.com / GuangHai Qi. Tel: +86-10-82107317, Fax: +86-10-82106054, E-mail: qiguanghai@caas.cn

${ }^{a}$ These authors contributed equally to this study.

Submitted Mar. 3, 2015; Revised May 2, 2015; Accepted Jun. 8, 2015
}

effects of various dietary protein sources on egg quality are relatively scarce.

Traditionally, SBM has been used as the preferred protein ingredient in the diets of laying hens due to its high nutritional value and favorable amino acid profile, close to the ideal model (Martens et al., 2012). However, the higher price of SBM prevents the inclusion of a higher ratio of SBM in the diet. The development of alternatives to SBM or new protein ingredients is a long-term task for animal nutritionists. In recent years, with the advancement of rape breeding, rapeseed meal or double-zero rapeseed meal (DRM, such as canola meal) is widely used as a protein ingredient for poultry and serves as a good source of wellbalanced amino acids (AA), sulfur-containing AA in particular (Khajali and Slominski, 2012). However, published works on DRM mainly focus on broilers (Woyengo et al., 2010; Jung et al., 2012). In addition, great 
progress has been made in effectively removing free gossypol (FG) from cottonseed meal. Cottonseed protein (CSP), one of the deep-processed products of cottonseed meal, is a good source of well-balanced and high nutritional value. Since 2008, China officially has promulgated cottonseed protein as potential alternative protein ingredient in place of SBM.

Freshly laid eggs are normally kept in cool conditions soon after laying, as prolonged exposure to elevated temperatures will deteriorate egg quality and increase microbial growth (Keener et al., 2001). In addition, our preliminary trial observed that there was some influence of dietary protein sources on fresh egg quality of Jinghong laying hens during peaking period (data not shown). However, whether these plant protein ingredients affect the internal quality of the egg under refrigerated conditions is not clear. This information is very important in understanding how to improve the utilization of dietary nutrients formulated with these plant protein ingredients. Therefore, a study was undertaken aiming to assess the effects of different plant protein ingredients on the internal quality of raw and cooked shell eggs under refrigerated conditions.

\section{MATERIALS AND METHODS}

\section{Egg preparation}

This study was approved by the Animal Care and Use Committee of the Feed Research Institute of the Chinese Academy of Agricultural Sciences. Three hundred and sixty Jinghong laying hens of $32 \mathrm{wk}$ of age were randomly allotted to six treatment groups that received variations in dietary protein sources, including SBM, CSP, or DRM individually or in combinations of two different protein sources, in which each ingredient provided an equal amount of crude protein in the diet. The specific treatment groups were as follows: SBM, SBM-CSP, CSP, SBM-DRM, DRM, and CSP-DRM. Each treatment consisted of five replicates with three cages each and four hens per cage. The cages were made of galvanized metal wire (approximately 55 $\mathrm{cm} \times 37 \mathrm{~cm} \times 40 \mathrm{~cm})$. Each cage included a nipple waterer, and all hens were provided feed and water ad libitum. The temperature and relative humidity $(\mathrm{RH})$ of the housing were $14^{\circ} \mathrm{C} \pm 2{ }^{\circ} \mathrm{C}$ and $50 \%$ to $65 \%$, respectively, and the photoperiod was set at $16 \mathrm{~L}: 8 \mathrm{D}$ throughout the 12 -wk feeding period. The hens were fed a mashed diet, and all nutrient levels met or exceeded the NRC requirements (National Research Council, 1994). A total of 270 eggs were collected over two consecutive days when the laying hens were 45 wk old. The eggs were screened for desirable weight range (close to the average egg weight for each replicate) and no defects (crack and breakage) and were weighed using an electronic balance (ALC-2000.2,
Sartorius Group, Acculab, Gottingen, Germany). The dietary composition and nutrient levels and the AA Pattern of standardized ileal digestibility (SID) of the diets are shown in Table 1 and 2.

\section{Experimental design and storage of eggs}

A total of 90 fresh eggs were collected and measured for egg quality within $24 \mathrm{~h}$ after laying. The other 180 eggs were used in a factorial arrangement with six dietary protein sources and two storage times as the main effects. Each of the 30 eggs was placed small-end down (Kim et al., 2009) on egg racks and stored in the cool room of a refrigerator $\left(4^{\circ} \mathrm{C}\right)$. The $\mathrm{RH}$ was regulated at $50 \%$ to $60 \%$ for all treatments. Egg quality measurements were performed on 15 eggs per treatment at intervals of 2 wk during the 4-wk period at $4^{\circ} \mathrm{C}$.

\section{Measurement of weight loss, Haugh unit, yolk index and albumen pH}

The weight loss of the whole egg $(\%)$ was calculated as follows: ([initial whole egg weight $\{\mathrm{g}\}$ at day 0 - whole egg weight (g) after storage]/initial whole egg weight $(\mathrm{g})$ at day $0) \times 100$, as reported by Wardy et al. (2013). The Haugh unit (HU) of each egg was measured using the Egg Analyzer (Orka Food Technology Ltd., Ramat Hasharon, Israel). An egg quality measurement stand (Fuji Ping Industrial Co. Ltd., Tokyo, Japan) and a vernier caliper (General Tools \& Instruments, New York, NY, USA) were used to measure the yolk width $(\mathrm{mm})$, and the yolk index was computed as (yolk height $[\mathrm{mm}] /$ yolk width $[\mathrm{mm}])$ (Stadelman, 1995). The albumen $\mathrm{pH}$ was measured using a $\mathrm{pH} /$ temperature measuring instrument (Testo AG, Lenzkirch, Germany) after thoroughly mixing both the thick and thin albumen. Ten measurements were performed for each treatment.

\section{Measurement of hardness and springiness of cooked yolk}

The eggs were placed in an egg cooker for $10 \mathrm{~min}$, and then the eggshell and egg white were stripped, ensuring the integrity of the egg yolk to the greatest extent. The hardness and springiness of the cooked yolk were measured using the texture profile analysis of the TMS-Pro Texture Analyzer (Food Technology Co., Sterling, VA, USA). The parameters were employed as follows: yolk deformation, $50 \%$; detection speed, $30 \mathrm{~mm} / \mathrm{min}$; probe pick up to the sample surface height, $40 \mathrm{~mm}$; input force sensing element, $24 \mathrm{~N}$; and force sensing element diameter: $38.15 \mathrm{~mm}$ and height: $20.00 \mathrm{~mm}$. Five measurements were performed for each treatment.

\section{Statistical analysis}

All of the data were analyzed by analysis of variance (ANOVA) using the general linear model procedures (SPSS 
Table 1. Dietary composition and nutrient levels of the experimental diets (as-fed basis)

\begin{tabular}{|c|c|c|c|c|c|c|}
\hline \multirow{2}{*}{ Item } & \multicolumn{6}{|c|}{ Treatment group $^{1}$} \\
\hline & SBM & SBM-CSP & CSP & SBM-DRM & DRM & CSP-DRM \\
\hline \multicolumn{7}{|l|}{ Ingredient (\%) } \\
\hline Corn & 62.64 & 65.00 & 67.00 & 58.00 & 56.60 & 63.10 \\
\hline $\mathrm{SBM}, 44.82 \% \mathrm{CP}$ & 25.00 & 11.76 & - & 12.84 & - & - \\
\hline CSP, $52.73 \%$ CP & - & 10.00 & 18.70 & - & - & 9.92 \\
\hline DRM, $38.73 \%$ CP & - & - & - & 14.87 & 29.20 & 13.52 \\
\hline Soybean oil & 0.02 & 0.98 & 0.67 & 1.35 & 1.82 & 0.90 \\
\hline L-Lysine-HCl, 78\% & 0.041 & 0.300 & 0.533 & 0.141 & 0.265 & 0.409 \\
\hline DL-Methionine, $98 \%$ & 0.167 & 0.186 & 0.203 & 0.146 & 0.126 & 0.166 \\
\hline L-Tryptophan, 99\% & 0.006 & 0.024 & 0.042 & 0.013 & 0.025 & 0.034 \\
\hline L-Threonine, $98 \%$ & 0.032 & 0.129 & 0.217 & 0.050 & 0.078 & 0.152 \\
\hline L-Isoleucine, $99 \%$ & 0.025 & 0.156 & 0.275 & 0.089 & 0.163 & 0.221 \\
\hline L-Valine, $99 \%$ & 0.011 & 0.099 & 0.182 & 0.040 & 0.080 & 0.133 \\
\hline L-Cysteine, 99\% & 0.149 & 0.161 & 0.174 & 0.100 & 0.059 & 0.120 \\
\hline Arginine, $99 \%$ & - & - & - & - & 0.082 & - \\
\hline Calcium hydrogen phosphate & 1.00 & 1.00 & 1.00 & 1.00 & 1.00 & 1.00 \\
\hline Calcium carbonate & 9.07 & 9.09 & 9.10 & 8.90 & 8.75 & 8.94 \\
\hline Salt & 0.30 & 0.30 & 0.30 & 0.30 & 0.30 & 0.30 \\
\hline Zeolite powder & 0.969 & 0.245 & 1.034 & 1.591 & 0.882 & 0.515 \\
\hline $\operatorname{Premix}^{2}$ & 0.57 & 0.57 & 0.57 & 0.57 & 0.57 & 0.57 \\
\hline Total & 100 & 100 & 100 & 100 & 100 & 100 \\
\hline \multicolumn{7}{|l|}{ Calculated analysis $^{3}$} \\
\hline $\mathrm{ME}(\mathrm{kcal} / \mathrm{kg})$ & 2655 & 2655 & 2655 & 2655 & 2655 & 2655 \\
\hline $\mathrm{CP}(\%)$ & $16.5(16.52)$ & $16.5(16.53)$ & $16.5(16.47)$ & $16.5(16.53)$ & $16.5(16.48)$ & $16.5(16.49)$ \\
\hline $\mathrm{EE}(\%)$ & $(1.07)$ & $(2.02)$ & $(1.47)$ & $(2.25)$ & $(3.54)$ & $(1.86)$ \\
\hline Calcium (\%) & $3.48(3.45)$ & $3.47(3.46)$ & $3.46(3.47)$ & $3.48(3.45)$ & $3.48(3.49)$ & $3.47(3.45)$ \\
\hline Non-phytate phosphorus (\%) & 0.41 & 0.39 & 0.38 & 0.39 & 0.38 & 0.39 \\
\hline Lysine (\%) & $0.896(1.03)$ & $0.930(1.05)$ & $0.959(1.16)$ & $0.922(1.06)$ & $0.944(1.16)$ & $0.952(1.34)$ \\
\hline Methionine (\%) & $0.427(0.45)$ & $0.440(0.45)$ & $0.450(0.40)$ & $0.439(0.39)$ & $0.449(0.39)$ & $0.449(0.42)$ \\
\hline Methionine + cysteine $(\%)$ & $0.807(0.78)$ & $0.825(0.78)$ & $0.839(0.80)$ & $0.834(0.77)$ & $0.860(0.82)$ & $0.849(0.84)$ \\
\hline Isoleucine $(\%)$ & $0.717(0.71)$ & $0.703(0.73)$ & $0.744(0.67)$ & $0.735(0.74)$ & $0.751(0.79)$ & $0.746(0.68)$ \\
\hline Threonine (\%) & $0.666(0.73)$ & $0.679(0.68)$ & $0.689(0.71)$ & $0.697(0.70)$ & $0.726(0.78)$ & $0.706(0.74)$ \\
\hline Tryptophan (\%) & $0.194(0.199)$ & $0.198(0.196)$ & $0.202(0.200)$ & $0.201(0.200)$ & $0.284(0.258)$ & $0.204(0.200)$ \\
\hline Valine $(\%)$ & $0.802(0.85)$ & $0.823(0.89)$ & $0.843(0.85)$ & $0.827(0.82)$ & $0.850(0.85)$ & $0.845(0.84)$ \\
\hline Arginine (\%) & $1.090(1.07)$ & $1.254(1.24)$ & $1.388(1.39)$ & $0.988(0.98)$ & $0.945(1.07)$ & $1.141(1.32)$ \\
\hline Histidine (\%) & $0.473(0.49)$ & $0.445(0.47)$ & $0.418(0.40)$ & $0.455(0.39)$ & $0.430(0.41)$ & $0.424(0.35)$ \\
\hline Leucine $(\%)$ & $1.473(1.45)$ & $1.325(1.36)$ & $1.188(1.01)$ & $1.404(1.45)$ & $1.328(1.44)$ & $1.258(1.18)$ \\
\hline Cystine (\%) & $0.380(0.33)$ & $0.385(0.33)$ & $0.389(0.40)$ & $0.395(0.38)$ & $0.411(0.43)$ & $0.400(0.42)$ \\
\hline Phenylalanine (\%) & $0.793(0.82)$ & $0.781(0.93)$ & $0.764(0.56)$ & $0.723(0.83)$ & $0.639(0.83)$ & $0.706(0.71)$ \\
\hline \multicolumn{7}{|l|}{ Anti-nutritional factor } \\
\hline Free gossypol (mg/kg) & - & 30.25 & 56.57 & - & - & 30.01 \\
\hline Isothiocyanate (mg/kg) & - & - & - & ND & ND & ND \\
\hline Oxazolidine thioketone $(\mathrm{mg} / \mathrm{g})$ & - & - & - & 0.050 & 0.099 & 0.046 \\
\hline
\end{tabular}

$\mathrm{HCl}$, hydrochloride; ME, metabolizable energy; $\mathrm{CP}$, crude protein; EE, ether extract; ND, not detected;

${ }^{1}$ The dietary types included soybean meal (SBM), cottonseed protein (CSP), double-zero rapeseed meal (DRM) individually or in combination with equal crude protein (SBM-CSP, SBM-DRM, and CSP-DRM) as the protein ingredient(s).

${ }^{2}$ Provided per kilogram of diet: vitamin A, 12,500 IU; vitamin $\mathrm{D}_{3}, 4,125 \mathrm{IU}$; vitamin E, $15 \mathrm{IU}$; vitamin $\mathrm{K}, 2 \mathrm{mg}$; vitamin $\mathrm{B}_{1}, 0.98 \mathrm{mg}$; vitamin $\mathrm{B}_{2}$, $8.5 \mathrm{mg}$; calcium pantothenate, $50 \mathrm{mg}$; niacin $32.5 \mathrm{mg}$; pyridoxine, $8 \mathrm{mg}$; biotin, $2 \mathrm{mg}$; folic acid $5 \mathrm{mg}$; vitamin $\mathrm{B}_{12}, 5 \mathrm{mg}$; copper, $8 \mathrm{mg}$; iodine, $1 \mathrm{mg}$; iron, 60 mg; selenium, $0.3 \mathrm{mg}$; manganese, $65 \mathrm{mg}$; zinc, $66 \mathrm{mg}$; choline, $0.5 \mathrm{~g}$; phytase, $0.5 \mathrm{~g}$; yeast culture ${ }^{\circledR}, 2.0 \mathrm{~g}$.

${ }^{3}$ Data regarding nutrients represent both the calculated value and analyzed value (in parentheses) except for ME (metabolizable energy) and non-phytate P. 
Table 2. AA Pattern of SID and AA concentration in the experimental diets ${ }^{1}$

\begin{tabular}{|c|c|c|c|c|c|c|}
\hline \multirow{2}{*}{ Nutrient (\%) } & \multicolumn{6}{|c|}{ Treatment group $^{2}$} \\
\hline & SBM & SBM-CSP & CSP & SBM-DRM & DRM & CSP-DRM \\
\hline $\mathrm{ME}(\mathrm{cal} / \mathrm{kg})$ & 2,655 & 2,655 & 2,655 & 2,655 & 2,655 & 2,655 \\
\hline $\mathrm{CP}(\%)$ & 16.5 & 16.5 & 16.5 & 16.5 & 16.5 & 16.5 \\
\hline SID Lys (\%) & 0.813 & 0.813 & 0.813 & 0.813 & 0.813 & 0.813 \\
\hline SID Met (\%) & 0.407 & 0.407 & 0.407 & 0.407 & 0.407 & 0.407 \\
\hline SID Met+Cys (\%) & 0.741 & 0.741 & 0.741 & 0.741 & 0.741 & 0.741 \\
\hline SID Ile (\%) & 0.651 & 0.651 & 0.651 & 0.651 & 0.651 & 0.651 \\
\hline SID Thr (\%) & 0.570 & 0.570 & 0.570 & 0.570 & 0.570 & 0.570 \\
\hline SID Trp (\%) & 0.171 & 0.171 & 0.171 & 0.171 & 0.171 & 0.171 \\
\hline SID Val (\%) & 0.716 & 0.716 & 0.716 & 0.716 & 0.716 & 0.716 \\
\hline SID Arg (\%) & 1.014 & 1.136 & 1.234 & 0.899 & 0.846 & 1.013 \\
\hline SID His (\%) & 0.440 & 0.399 & 0.361 & 0.412 & 0.379 & 0.370 \\
\hline SID Leu (\%) & 1.342 & 1.165 & 1.003 & 1.250 & 1.155 & 1.079 \\
\hline SID Cys (\%) & 0.336 & 0.225 & 0.216 & 0.266 & 0.296 & 0.254 \\
\hline SID Phe (\%) & 0.717 & 0.683 & 0.649 & 0.640 & 0.552 & 0.604 \\
\hline SID Lys:Lys & 100 & 100 & 100 & 100 & 100 & 100 \\
\hline SID Met:Lys & 50 & 50 & 50 & 50 & 50 & 50 \\
\hline SID Met+Cys:Lys & 91 & 91 & 91 & 91 & 91 & 91 \\
\hline SID Ile:Lys & 80 & 80 & 80 & 80 & 80 & 80 \\
\hline SID Thr:Lys & 70 & 70 & 70 & 70 & 70 & 70 \\
\hline SID Trp:Lys & 21 & 21 & 21 & 21 & 21 & 21 \\
\hline SID Val:Lys & 88 & 88 & 88 & 88 & 88 & 88 \\
\hline SID Arg:Lys & 125 & 140 & 152 & 111 & 104 & 125 \\
\hline
\end{tabular}

AA, amino acids; SID, standardized ileal digestible; ME, metabolizable energy; CP, crude protein.

${ }^{1}$ All of the data represent calculated values.

${ }^{2}$ The dietary types included soybean meal (SBM), cottonseed protein (CSP), double-zero rapeseed meal (DRM) individually or in combination with equal crude protein (SBM-CSP, SBM-DRM, and CSP-DRM) as the protein ingredient(s).

ver. 19.0, SPSS Inc., Chicago, IL, USA) as a $6 \times 3$ factorial arrangements with dietary type and storage time as the main effects. One-way ANOVA was also used to analyze the differences among all treatments when the interaction was significant, and then Duncan's multiple range tests were used to separate the mean values. All statements of significance are based on $p<0.05$ unless otherwise specified.

\section{RESULTS}

\section{Haugh unit and albumen pH of raw eggs}

The effect of dietary protein sources and storage time on the $\mathrm{HU}$ of raw eggs is shown in Table 3. The dietary protein sources significantly affected the $\mathrm{HU}$ parameters. The HU of the eggs in the CSP, SBM-DRM, and DRM groups were lower than those in the SBM and SBM-CSP groups, and the DRM diet group showed the lowest value $(\mathrm{p}<0.05)$. Storage time remarkably affected the $\mathrm{HU}$ of raw eggs, with a decrease in HU observed with storage time $(\mathrm{p}<0.05)$. A significant interaction between dietary type and storage time was also observed $(\mathrm{p}<0.05)$. The $\mathrm{HU}$ of the eggs in the SBM-DRM and DRM groups showed lower levels than those in the other groups when stored to 4 wk at $4^{\circ} \mathrm{C}$ $(\mathrm{p}<0.05)$. The HU of the eggs was higher in the SBM-CSP group compared with the other groups during storage.

Table 3 shows the effect of the dietary protein sources and storage time on the albumen $\mathrm{pH}$ of raw eggs. The dietary protein sources did not affect the albumen $\mathrm{pH}$ of the eggs, although storage time significantly affected the albumen $\mathrm{pH}$ of raw eggs. The albumen $\mathrm{pH}$ of fresh eggs $(0$ d) was lower than that of stored eggs, especially when stored for 4 wk at $4^{\circ} \mathrm{C}(\mathrm{p}<0.05)$. A significant interaction between dietary protein type and storage time was observed regarding the albumen $\mathrm{pH}$ of the eggs $(\mathrm{p}<0.05)$. Specifically, the albumen $\mathrm{pH}$ (8.92) of the eggs was higher in the DRM group than in the SBM and SBM-CSP groups when stored for 4 wk at $4^{\circ} \mathrm{C}(\mathrm{p}<0.05)$.

\section{Weight loss and yolk index of raw eggs}

The dietary protein sources did not affect the weight loss of the eggs ( $p>0.05$; Table 3). Storage time significantly increased the weight loss of the eggs under refrigerated conditions $(\mathrm{p}<0.05)$, although no interactions were observed between the dietary protein sources and the storage time on the weight loss of the eggs ( $>>0.05)$. The dietary protein sources also did not affect the yolk index, although the yolk index of raw eggs significantly decreased 
Table 3. Effect of dietary types and storage time on raw egg quality

\begin{tabular}{|c|c|c|c|c|c|}
\hline \multirow{2}{*}{ Item } & \multirow{2}{*}{ Dietary type $^{1}$} & \multicolumn{2}{|c|}{ Albumen quality parameter } & \multirow{2}{*}{ Weight loss (\%) } & \multirow{2}{*}{ Yolk index } \\
\hline & & Haugh unit & Albumen $\mathrm{pH}$ & & \\
\hline \multicolumn{6}{|l|}{ Time of storage } \\
\hline \multirow[t]{6}{*}{$0 \mathrm{wk}$} & SBM & $81.63^{\mathrm{ab}}$ & $8.29^{\mathrm{hi}}$ & 0.00 & $0.429^{\mathrm{cd}}$ \\
\hline & SBM-CSP & $82.03^{\mathrm{a}}$ & $8.27^{\mathrm{hi}}$ & 0.00 & $0.450^{\mathrm{bc}}$ \\
\hline & CSP & $76.13^{\text {cde }}$ & $8.41^{\mathrm{g}}$ & 0.00 & $0.433^{\mathrm{cd}}$ \\
\hline & SBM-DRM & $81.35^{\mathrm{ab}}$ & $8.22^{\mathrm{i}}$ & 0.00 & $0.481^{\mathrm{a}}$ \\
\hline & DRM & $76.67^{\mathrm{cd}}$ & $8.20^{\mathrm{i}}$ & 0.00 & $0.466^{\mathrm{ab}}$ \\
\hline & CSP-DRM & $81.17^{\mathrm{ab}}$ & $8.32^{\mathrm{h}}$ & 0.00 & $0.485^{\mathrm{a}}$ \\
\hline \multirow[t]{6}{*}{$2 \mathrm{wk}$} & SBM & $76.40^{\mathrm{cd}}$ & $8.69^{\mathrm{ef}}$ & 1.00 & $0.417^{\mathrm{def}}$ \\
\hline & SBM-CSP & $78.50^{\mathrm{bc}}$ & $8.64^{\mathrm{f}}$ & 1.02 & $0.413^{\text {defg }}$ \\
\hline & CSP & $75.11^{\mathrm{cde}}$ & $8.71^{\mathrm{ef}}$ & 1.08 & $0.418^{\mathrm{de}}$ \\
\hline & SBM-DRM & $67.25^{\mathrm{g}}$ & $8.72^{\mathrm{def}}$ & 1.01 & $0.403^{\text {efghi }}$ \\
\hline & DRM & $66.98^{\mathrm{g}}$ & $8.77^{\text {cde }}$ & 1.06 & $0.379^{\mathrm{ij}}$ \\
\hline & CSP-DRM & $72.84^{\mathrm{ef}}$ & $8.68^{\mathrm{ef}}$ & 1.05 & $0.390^{\text {ghij }}$ \\
\hline \multirow[t]{6}{*}{$4 \mathrm{wk}$} & SBM & $73.94^{\mathrm{def}}$ & $8.82^{\mathrm{bc}}$ & 1.48 & $0.400^{\text {efghi }}$ \\
\hline & SBM-CSP & $76.52^{\mathrm{cd}}$ & $8.81^{\mathrm{bcd}}$ & 1.35 & $0.404^{\mathrm{efgh}}$ \\
\hline & CSP & $72.71^{\mathrm{ef}}$ & $8.84^{\mathrm{abc}}$ & 1.48 & $0.393^{\text {fghij }}$ \\
\hline & SBM-DRM & $66.85^{\mathrm{g}}$ & $8.90^{\mathrm{ab}}$ & 1.45 & $0.390^{\text {ghij }}$ \\
\hline & DRM & $66.13^{\mathrm{g}}$ & $8.92^{\mathrm{a}}$ & 1.53 & $0.371^{\mathrm{j}}$ \\
\hline & CSP-DRM & $71.44^{\mathrm{f}}$ & $8.86^{\mathrm{abc}}$ & 1.48 & $0.385^{\text {hij }}$ \\
\hline Pooled SEM & & 0.324 & 0.007 & 0.009 & 0.002 \\
\hline \multicolumn{6}{|l|}{ Mean values of main effects } \\
\hline \multirow[t]{6}{*}{ Dietary type } & SBM & $77.32^{\mathrm{ab}}$ & 8.60 & 0.83 & $0.415^{\mathrm{ab}}$ \\
\hline & SBM-CSP & $79.02^{\mathrm{a}}$ & 8.58 & 0.79 & $0.422^{\mathrm{a}}$ \\
\hline & CSP & $74.65^{\mathrm{c}}$ & 8.65 & 0.85 & $0.415^{\mathrm{ab}}$ \\
\hline & SBM-DRM & $71.82^{\mathrm{d}}$ & 8.62 & 0.82 & $0.424^{\mathrm{a}}$ \\
\hline & DRM & $69.93^{\mathrm{d}}$ & 8.63 & 0.87 & $0.405^{\mathrm{b}}$ \\
\hline & CSP-DRM & $75.15^{\mathrm{bc}}$ & 8.62 & 0.84 & $0.420^{\mathrm{a}}$ \\
\hline \multirow[t]{3}{*}{ Storage time } & $0 \mathrm{wk}$ & $79.83^{\mathrm{a}}$ & $8.28^{\mathrm{c}}$ & $0.00^{\mathrm{c}}$ & $0.457^{\mathrm{a}}$ \\
\hline & $2 \mathrm{wk}$ & $72.85^{\mathrm{b}}$ & $8.70^{\mathrm{b}}$ & $1.04^{\mathrm{b}}$ & $0.403^{\mathrm{b}}$ \\
\hline & $4 \mathrm{wk}$ & $71.27^{\mathrm{b}}$ & $8.86^{\mathrm{a}}$ & $1.46^{\mathrm{a}}$ & $0.390^{\mathrm{c}}$ \\
\hline \multicolumn{6}{|l|}{ Source of variation, $\mathrm{p}$-value } \\
\hline Dietary types & & $<0.001$ & 0.057 & 0.243 & 0.034 \\
\hline Storage time & & $<0.001$ & $<0.001$ & $<0.001$ & $<0.001$ \\
\hline Dietary types $\times$ storage time & & 0.001 & $<0.001$ & 0.616 & $<0.001$ \\
\hline
\end{tabular}

SEM, standard error of mean values $(\mathrm{n}=180)$.

${ }^{1}$ The dietary types included soybean meal (SBM), cottonseed protein (CSP), double-zero rapeseed meal (DRM) individually or in combination with equal crude protein (SBM-CSP, SBM-DRM, and CSP-DRM) as the protein ingredient(s).

${ }^{\mathrm{a}-\mathrm{j}}$ Mean values within a column without common superscripts differ significantly $(\mathrm{p}<0.05)$.

with increasing storage time $(\mathrm{p}<0.05)$. A significant interaction was noted between the dietary protein sources and storage time regarding the yolk index during storage $(\mathrm{p}<0.05)$. In particular, a remarkable decline in the yolk index was observed in the DRM group compared with the SBM and SBM-CSP groups after storage for $4 \mathrm{wk}(\mathrm{p}<0.05)$.

\section{Hardness and springiness of cooked yolk}

Table 4 illustrates the effect of the dietary protein type and storage time on the hardness of the cooked yolks. The dietary protein sources significantly affected the hardness of the cooked yolks, with the yolks in the CSP group showing greater hardness than the other groups $(\mathrm{p}<0.05)$. The hardness of the cooked yolks after 4 wk of storage was significantly higher than those values at $0 \mathrm{~d}$ and 2 wk under refrigerated conditions $(\mathrm{p}<0.05)$, and a significant interaction was observed between the dietary type and storage time on the hardness of the cooked yolks during storage $(\mathrm{p}<0.05)$. The hardness of the cooked yolks increased dramatically in the CSP group when stored under refrigerated conditions $(p<0.05)$, whereas the hardness of the cooked yolks remained unaffected in the laying hens fed 
Table 4. Effect of dietary types and storage time on hardness and springiness of cooked yolks

\begin{tabular}{|c|c|c|c|}
\hline Item & Dietary type $^{1}$ & $\begin{array}{l}\text { Hardness } \\
(\mathrm{N})\end{array}$ & $\begin{array}{l}\text { Springiness } \\
(\mathrm{mm})\end{array}$ \\
\hline \multicolumn{4}{|l|}{ Time of storage } \\
\hline \multirow[t]{6}{*}{0 wk } & SBM & $3.798^{\mathrm{bc}}$ & 3.890 \\
\hline & SBM-CSP & $4.060^{\mathrm{bc}}$ & 4.104 \\
\hline & CSP & $4.114^{\mathrm{bc}}$ & 4.878 \\
\hline & SBM-DRM & $4.033^{\mathrm{bc}}$ & 4.194 \\
\hline & DRM & $4.592^{\mathrm{bc}}$ & 3.946 \\
\hline & CSP-DRM & $4.875^{\mathrm{b}}$ & 5.312 \\
\hline \multirow[t]{6}{*}{$2 \mathrm{wk}$} & SBM & $3.488^{b c}$ & 4.372 \\
\hline & SBM-CSP & $3.827^{\mathrm{bc}}$ & 4.568 \\
\hline & CSP & $8.312^{\mathrm{a}}$ & 5.874 \\
\hline & SBM-DRM & $3.684^{\mathrm{bc}}$ & 4.524 \\
\hline & DRM & $2.920^{\mathrm{c}}$ & 3.496 \\
\hline & CSP-DRM & $3.558^{\mathrm{bc}}$ & 4.364 \\
\hline \multirow[t]{6}{*}{$4 \mathrm{wk}$} & SBM & $4.906^{\mathrm{b}}$ & 4.540 \\
\hline & SBM-CSP & $4.919^{\mathrm{b}}$ & 4.464 \\
\hline & CSP & $9.172^{\mathrm{a}}$ & 5.348 \\
\hline & SBM-DRM & $3.754^{\mathrm{bc}}$ & 4.292 \\
\hline & DRM & $3.893^{\mathrm{bc}}$ & 4.842 \\
\hline & CSP-DRM & $3.443^{\mathrm{bc}}$ & 4.506 \\
\hline Pooled SEM & & $0.127^{b c}$ & 0.119 \\
\hline \multicolumn{4}{|c|}{ Mean values of main effects } \\
\hline \multirow[t]{6}{*}{ Dietary type } & SBM & $4.064^{\mathrm{b}}$ & $4.267^{\mathrm{b}}$ \\
\hline & SBM-CSP & $4.269^{\mathrm{b}}$ & $4.379^{\mathrm{b}}$ \\
\hline & CSP & $7.199^{\mathrm{a}}$ & $5.367^{\mathrm{a}}$ \\
\hline & SBM-DRM & $3.824^{\mathrm{b}}$ & $4.337^{\mathrm{b}}$ \\
\hline & DRM & $3.802^{\mathrm{b}}$ & $4.095^{\mathrm{b}}$ \\
\hline & CSP-DRM & $3.959^{\mathrm{b}}$ & $4.727^{\mathrm{ab}}$ \\
\hline \multirow[t]{3}{*}{ Storage time } & 0 & $4.245^{\mathrm{b}}$ & 4.387 \\
\hline & $2 \mathrm{wk}$ & $4.298^{\mathrm{b}}$ & 4.533 \\
\hline & $4 \mathrm{wk}$ & $5.015^{\mathrm{a}}$ & 4.665 \\
\hline \multicolumn{4}{|c|}{ Source of variation, $p$-value } \\
\hline \multicolumn{2}{|l|}{ Dietary types } & $<0.001$ & 0.038 \\
\hline \multicolumn{2}{|l|}{ Storage time } & 0.029 & 0.635 \\
\hline \multicolumn{2}{|c|}{ Dietary types $\times$ storage time } & $<0.001$ & 0.593 \\
\hline \multicolumn{4}{|c|}{$\begin{array}{l}\text { SEM, standard error of mean values }(\mathrm{n}=90) \text {. } \\
{ }^{1} \text { The dietary types included soybean meal }(\mathrm{SBM}) \text {, cottonseed protein } \\
(\mathrm{CSP}) \text {, double-zero rapeseed meal }(\mathrm{DRM}) \text { individually or in combination } \\
\text { with equal crude protein (SBM-CSP, SBM-DRM, and CSP-DRM) as the } \\
\text { protein ingredient(s). }\end{array}$} \\
\hline
\end{tabular}

\section{the SBM-CSP or CSP-DRM diet.}

The CSP diet significantly increased the springiness of the cooked yolks $(\mathrm{p}<0.05)$ compared with the other diets except for the CSP-DRM diet (Table 4). The storage time did not affect the springiness of the cooked yolks $(\mathrm{p}>0.05)$. No interactions were observed between the dietary protein sources and the storage time regarding the springiness of the cooked yolks ( $p>0.05)$.

\section{DISCUSSION}

In the current study, all diets were formulated at a fixed dietary energy concentration $(2,655 \mathrm{kcal}$ of $\mathrm{AME} / \mathrm{kg})$ and $\mathrm{CP}$ content $(16.5 \%)$, and the profile of different essential AA (SID) in relation to lysine remained constant in all of the diets. The current study showed that replacement of half of the crude protein of dietary CSP with SBM or DRM (SBM-CSP, CSP-DRM) may alleviate the adverse effect of CSP on the cooked yolk hardness of refrigerated eggs. Using CSP to replace DRM with equal crude protein may also improve the adverse effect of DRM on the HU of raw eggs. The internal quality (except yolk springiness) of the raw and cooked shell eggs decreased during storage.

The HU is calculated from the height of the inner thick albumen and the weight of an egg (Haugh, 1937), while the numerical value mainly reflects the thick albumin content of the egg. The viscosity of the thick white gives the egg white its viscous character and is conferred by a glycoprotein ovomucin (Brooks and Hale, 1959; Omana et al., 2010), and the HU value was mainly influenced by ovomucin content of egg. In this study, a remarkable reduction in $\mathrm{HU}$ was observed in the SBM-DRM and DRM groups compared with the other groups under refrigerated condition. Nevertheless, the reduced $\mathrm{HU}$ resulting from the DRM diet was partially ameliorated by the combination of CSP in different dietary treatments. Previous studies have demonstrated that the major effect on $\mathrm{HU}$ are the strain and age of the hen laying the egg and the storage time and conditions (Shafer et al., 1998; Silversides and Scott, 2001). It might be affected by the egg white thinning which was due to the deterioration of the ovomucin gel structure at elevated $\mathrm{pH}$ during storage (Wang et al., 2012). Therefore, we assumed that the HU was influenced by the ovomucin content of egg in the current experiment. However, specific mechanism of dietary protein sources on $\mathrm{HU}$ of chicken eggs under refrigerated conditions awaits further study.

We also found that dietary protein sources affected the hardness of the cooked yolk. In particular, a remarkable increase in yolk hardness was observed in the CSP group compared with the other groups. However, the replacement of CSP with an equal crude protein content of SBM or DRM alleviated the adverse effects on yolk hardness. Bai et al. (2014) found that $2 \%$ cottonseed oil in the diet increased the hardness of the egg yolks due to the FG residue in the yolk from the cottonseed oil. Another study showed that a diet containing FG $(200 \mathrm{~g} / \mathrm{kg})$ produced eggs with olive or brown yolk discoloration after cold storage (Gilani et al., 2012). However, we observed no layer mortality or yolk or albumen discoloration with the increase in hardness of the cooked yolk following the CSP diet. This result illustrated that the FG content $(56.57 \mathrm{mg} / \mathrm{kg})$ had no effect on the albumen or yolk color in the CSP group. However, the 
relationship between the FG content and the hardness of cooked yolks under refrigerated conditions requires further investigation.

Our study indicated that the HU and yolk index of raw eggs decreased, whereas the weight loss and albumen $\mathrm{pH}$ of raw eggs increased, with increased storage time at $4^{\circ} \mathrm{C}$, which was also observed in other studies (Caner and Cansiz, 2008; Kim et al., 2009; Jin et al., 2011; Wardy et al., 2013). Generally speaking, the HU, albumin $\mathrm{pH}$ and yolk index are considered to be indicators of egg quality, which can be used to indicate freshness (Waimaleongora-Ek et al., 2009; Wardy et al., 2013). However, the problems of weight loss and interior quality deterioration may be encountered during the storage of eggs (De Reu et al., 2006). Several possible reasons for those problems have been proposed, including the gradual deterioration of the gel structure of the thick albumen leading to albumen thinning (Kato et al., 1979; Nongtaodum et al., 2013); carbon dioxide loss from the breakdown of carbonic acid in the albumen leading to increased albumen $\mathrm{pH}$; and carbon dioxide and moisture escape via the eggshell pores leading to weight loss and reduction of the yolk index (Keener et al., 2000; Kemps et al., 2007; Caner and Cansiz, 2008; Biladeau and Keener, 2009). In addition, it was also found that yolk weight increased while the albumen weight decreased during storage (data not shown), which supported the concept of yolk uptake of moisture from the egg white (Hidalgo et al., 1996) leading to weakening of the yolk membrane and a reduction in the yolk index. One interesting result was that the hardness of the cooked yolk increased with storage time at $4^{\circ} \mathrm{C}$. This is problematic because higher hardness values are associated with a reduced texture quality of the cooked yolk and a poorer taste of the cooked yolk to consumers. In fact, published work regarding the effects of storage time on yolk hardness is very limited at present. Yang et al. (2011) reported that the increased hardness of Portunus pelagicus crabs during frozen storage was due to a change in protein composition. Therefore, the observed increase in yolk hardness may be due to changes in the yolk protein or structural material that occurred during storage at $4{ }^{\circ} \mathrm{C}$.

In the current study, we found that hens fed combinations of any two of the protein ingredients with similar crude protein contents (SBM-CSP, SBM-DRM, and CSP-DRM) showed improvements in the internal quality of raw and cooked shell eggs compared with hens fed the DRM or CSP diet. Among all treatment groups, the egg internal quality, yolk hardness and yolk springiness in the SBM-CSP group were very similar to those in the SBM group. Therefore, there may be a combined effect between dietary protein sources, and this finding indicates that additional choices for dietary protein sources are available for laying hens. In particular, this result may alleviate the problem of soybean shortages and also reduce the feed cost of laying hens.

\section{CONCLUSION}

In summary, dietary protein sources affected the internal quality of raw and water-cooked eggs during storage. In particular, CSP may inhibit the effects of DRM on decreased HU of raw eggs, whereas SBM or DRM may alleviate the adverse effects of CSP on the cooked yolk hardness of refrigerated eggs. Therefore, we speculate that there may be a combined effect between dietary protein sources on egg internal quality, and this information may provide additional choices regarding protein sources to egg producers.

\section{CONFLICT OF INTEREST}

We certify that there is no conflict of interest with any financial organization regarding the material discussed in the manuscript.

\section{ACKNOWLEDGMENTS}

This study was supported by the China Agriculture Research System (CARS-41-K13), the Agricultural Science and Technology Innovation Program (ASTIP), National Key Technology Research and Development Program (2011BAD26B03) and China Agriculture Research SystemBeijing Team for the Poultry Industry.

\section{REFERENCES}

Bai, K., H. Chen, X. H. Guo, S. Ge, and R. L. Huang. 2014. Effects of cottonseed oil on egg qualities and texture of boiled eggs. Heilongjiang Xumu Shouyi 2:80-83. (in Chinese)

Biladeau, A. M. and K. M. Keener. 2009. The effects of edible coatings on chicken egg quality under refrigerated storage. Poult. Sci. 88:1266-1274.

Brooks, J. and H. P. Hale. 1959. The mechanical properties of the thick white of the hen's egg. Biochim. Biophys. Acta. 32:237250

Caner, C. and Ö. Cansiz. 2008. Chitosan coating minimises eggshell breakage and improves egg quality. J. Sci. Food Agric. 88:56-61.

De Reu, K., K. Grijspeerdt, W. Messens, M. Heyndrickx, M. Uyttendaele, J. Debevere, and L. Herman. 2006. Eggshell factors influencing eggshell penetration and whole egg contamination by different bacteria, including Salmonella enteritidis. Int. J. Food Microbiol. 112:253-260.

Gilani, A., H. Kermanshahi, A. golian, and A. M. Tahmasbi. 2012. Alterations of egg yolk and albumen quality during cold storage when hens fed diets comprising cottonseed meal treated with sodium bentonite. Int. J. Appl. Anim. Sci. 1:74-79.

Haugh, R. R. 1937. The Haugh unit for measuring egg quality. U.S. Egg Poult. Mag. 43:552-555. 
Hidalgo, A., M. Lucisano, E. M. Comelli, and C. Pompei. 1996. Evolution of chemical and physical yolk characteristics during the storage of shell eggs. J. Agric. Food Chem. 44:1447-1452.

Jin, Y. H., K. T. Lee, W. I. Lee, and Y. K. Han. 2011. Effects of storage temperature and time on the quality of eggs from laying hens at peak production. Asian Australas. J. Anim. Sci. 24:279-284.

Jung, B., R. D. Mitchell, and A. B. Batal. 2012. Evaluation of the use of feeding distillers dried grains with solubles in combination with canola meal on broiler performance and carcass characteristics. J. Appl. Poult. Res. 21:776-787.

Kato, A., K. Ogino, Y. Kuramoto, and K. Kobayashi. 1979. Degradation of the O-glycosidically linked carbohydrate units of ovomucin during egg white thinning. J. Food Sci. 44:13411344.

Keener, K. M., J. D. LaCrosse, and J. K. Babson. 2001. Chemical method for determination of carbon dioxide content in egg yolk and egg albumen. Poult. Sci. 80:983-987.

Keener, K. M., J. D. LaCrosse, P. A. Curtis, K. E. Anderson, and B. E. Farkas. 2000. The influence of rapid air cooling and carbon dioxided cooling and subsequent storage in air and carbon dioxide on shell egg quality. Poult. Sci. 79:1067-1071.

Kemps, B. J., B. De Ketelaere, F. R. Bamelis, K. Mertens, E. M. Decuypere, J. G. De Baerdemaeker, and F. Schwägele. 2007. Albumen freshness assessment by combining visible nearinfrared transmission and low-resolution proton nuclear magnetic resonance spectroscopy. Poult. Sci. 86:752-759.

Khajali, F. and B. A. Slominski. 2012. Factors that affect the nutritive value of canola meal for poultry. Poult. Sci. 91:25642575.

Kim, S. H., D. K. Youn, H. K. No, S. W. Choi, and W. Prinyawiwatkul. 2009. Effects of chitosan coating and storage position on quality and shelf life of eggs. Int. J. Food Sci. Tech. 44:1351-1359.

Li, F., L. M. Zhang, X. H. Wu, C. Y. Li, X. J. Yang, Y. Dong, A. Lemme, J. C. Han, and J. H. Yao. 2013. Effects of metabolizable energy and balanced protein on egg production, quality, and components of Lohmann Brown laying hens. J. Appl. Poult. Res. 22:36-46.

Martens, S. D., T. T. Tiemann, J. Bindelle, M. Peters, and C. E. Lascano. 2012. Alternative plant protein sources for pigs and chickens in the tropics-nutritional value and constraints: a review. J. Agric. Rural Dev. Trop. Subtrop. 113:101-123.

National Research Council. 1994. Nutrient Requirements of Poultry. 9th ed. National Academy Press, Washington, DC, USA.
Nongtaodum, S., A. Jangchud, K. Jangchud, P. Dhamvithee, H. K. No, and W. Prinyawiwatkul. 2013. Oil coating affects internal quality and sensory acceptance of selected attributes of raw eggs during storage. J. Food Sci. 78:S329-S335

Omana, D. A., J. Wang, and J. Wu. 2010. Ovomucin-a glycoprotein with promising potential. Trends Food Sci. Technol. 21:455-463.

Rao, S. V. R., V. Ravindran, T. Srilatha, A. K. Panda, and M. V. L. N. Raju. 2011. Effect of dietary concentrations of energy, crude protein, lysine, and methionine on the performance of White Leghorn layers in the tropics. J. Appl. Poult. Res. 20:528-541.

Shafer, D. J., J. B. Carey, J. F. Prochaska, and A. R. Sams. 1998. Dietary methionine intake effects on egg component yield, composition, functionality, and texture profile analysis. Poult. Sci. 77:1056-1062.

Silversides, F. G. and T. A. Scott. 2001. Effect of storage and layer age on quality of eggs from two lines of hens. Poult. Sci. 80:1240-1245.

Stadelman, W. J. 1995. Quality identification of shell eggs. In: Egg Science and Technology, 4th Ed. (Eds. W. J. Stadelman, and O. J. Cotterill). Food Products Press, New York, NY, USA. pp. 37-65.

Tarasewicz, Z., D. Szczerbinska, M. Ligocki, M. Wiercinska, D. Majewska, and K. Romaniszyn. 2006. The effect of differentiated dietary protein level on the performance of breeder quails. Anim. Sci. Pap. Rep. 24:207-216.

Waimaleongora-Ek, P., K. M. Garcia, H. K. No, W. Prinyawiwatkul, and D. R. Ingram. 2009. Selected quality and shelf life of eggs coated with mineral oil with different viscosities. J. Food Sci. 74:S423-S429.

Wang, J., D. A. Omana, and J. Wu. 2012. Effect of shell eggs storage on ovomucin extraction. Food Bioprocess Tech. 5:2280-2284.

Wardy, W., D. D. Torrico, J. A. H. Corredor, H. K. No, X. Zhang, Z. Xu, and W. Prinyawiwatkul. 2013. Soybean oil-chitosan emulsion affects internal quality and shelf-life of eggs stored at 25 and $4^{\circ} \mathrm{C}$. Int. J. Food Sci. Tech. 48:1148-1156.

Woyengo, T. A., E. Kiarie, and C. M. Nyachoti. 2010. Metabolizable energy and standardized ileal digestible amino acid contents of expeller-extracted canola meal fed to broiler chicks. Poult. Sci. 89:1182-1189.

Yang, J. S., S. Y. Xia, Y. Fang, and K. Lin. 2011. Application of TPA in Portunus pelagicus and different freeze storage temperature on its quality. Food Sci. Technol. 36:129-135. (in Chinese). 